УДК 82.15 .09

DOI 10.25205/2542-0429-2021-21-1-136-149

\title{
Problems of the Project Management Approach Implementation in the Professional Guidance among Students
}

\author{
E. T. Meirkhanova, S. T. Kupeshova \\ Kazakh National University after Al-Farabi \\ Almaty, Kazakhstan
}

\begin{abstract}
The article revels the challenges of using project-based management for professional orientation of students at the senior stage of the secondary school in Republic of Kazakhstan. The competency-based approach as a fundamental paradigm has been identified for successful implementation of the projectbased management at the senior (high) stage of the secondary school, which, in turn, is a determining factor in the situation on the labor market. The stages of implementation of project-based management for professional orientation of high school students have been worked out. The current situation of project-based management implementation has been investigated based on sample.

Keywords

project-based management, labor economics, professional orientation, high school students, competency-based approach

For citation

Meirkhanova E. T., Kupeshova S. T. Problems of the Project Management Approach Implementation in the Professional Guidance among Students. World of Economics and Management, 2021, vol. 21, no. 1, p. 136-149. DOI 10.25205/2542-0429-2021-21-1-136-149
\end{abstract}

\section{Проблемы использования \\ инструментов проектного управления в профессиональной ориентации школьников}

\author{
Е. Т. Мейрханова, С. Т. Купешова \\ Казахский национальный университет им. Аль-Фараби \\ Алматы, Казахстан
}

Аннотация

В статье раскрыты актуальные проблемы использования проектного управления для профессиональной ориентации учащихся старших классов общеобразовательных школ. Компетентностный подход как фундаментальная парадигма определен для успешной реализации проектного управления на старшей (высшей) ступени общеобразовательной школы, что, в свою очередь, является определяющим фактором ситуации на рынке труда. Целью является разработка этапов внедрения проектного менеджмента для профессиональной ориентации старшеклассников. Исследована текущая ситуация с внедрением проектного менеджмента на примере выборки школ.

(C) Е. Т. Мейрханова, С. Т. Купешова, 2021 
Ключевые слова

проектное управление, экономика труда, профессиональная ориентация, компетентностный подход

Для цитирования

Meirkhanova E. T., Kupeshova S. T. Problems of the Project Management Approach Implementation in the Professional Guidance among Students // Мир экономики и управления. 2021. Т. 21, № 1. C. 136-149. DOI 10.25205/2542-0429-2021-21-1-136-149

\section{Introduction}

The Law of the Republic of Kazakhstan “About Education” 2007 and the Conception of Development of Profile Training in the Republic of Kazakhstan [1, p. 1-15] introduce profile education in high school. Profile education is one of instruments for helping students to choose their future profession; it is the professional guidance for them. Therefore, the content of profile education in senior classes of secondary school is realized within socio-humanitarian and natural-scientific directions. Moreover, the bulk of professionally oriented competencies is identified for senior stage of secondary school. It stipulates the development of speech competence, the improvement of speaking, listening, reading and writing skills and abilities to plan verbal and nonverbal behavior. Sociocultural competence with abilities to function in society effectively has also been identified for senior stage of the secondary school. Informationaleducative competence is in the center of profile education with professional selfdetermination, social adaptation and abilities to solve problems in a team through project work.

According to above mentioned Conception, the profile education in senior classes of secondary school represents the system of specialized preparation, which is focused on requirements of a labor market. The profile training presupposes the individualized education through changes in structure, content and organization of educational process to consider interests, tendencies and abilities of students, to create conditions for education of seniors according to their professional interests and intentions. The model of high school provides various combinations of training courses, on the basis of which flexible system of profile education is formed. These are three types of training courses: basic courses, profile and elective. Basic courses are obligatory for all students. Profile courses are aimed at vocational guidance of school students, their initial specialization in concrete subject domain. In order to provide vocational guidance, project activities are implemented into education process. Elective courses are obligatory courses for school senior students. They expand, supplement and alter a profile. This system does not limit schools in organization of this or that profile of training (or several profiles at the same time) and a school student has a choice of various sets of basic, profile and elective courses which make an individual educational trajectory.

Although professional guidance and informational-educative actions are recognized to be useful, real-world application of such activities are still questionable. Under such a doubt, in this research we defined that absence of defined measurable goals, success criteria, top-level requirements, basic events schedule, main stakeholders, team members, acceptance requirements and expected results lead to vague effectiveness. In this research we observed the way 'project activities' are organized. High teachers' contribution brings another problem. Weak students' involvement into 
school project, it's content, goals and source of knowledge alienate students from getting competence-based education and from real-life context. This, in its queue, can become a reason for lack of practical implementation of "project activities' and professional guidance. Since the aspects listed are basic instruments of Project Management, this research is aimed at implementation of Project Management instruments for professional orientation and school project activities to become naturally valid. Project activities need Project Management approach acting through listed above. In this research we suggest steps that cover them and analyze if they are applicable through questionnaire.

Competency-based approach is widely discussed by influential scholars. I. Zimnyaya defines competence as inner, potential, latent psychological development (knowledge, appearance, algorithms of activity, a system of values and relations) that are emerged and demonstrated in the performance of professional activities. She identifies three groups of key competencies: competence related to personal experience and values (health protection, axiological issues, knowledge enhancement, culture, selfdevelopment); competence related to social interaction (conflicts resolutions, cooperation, collaboration, tolerance, communication, respect and acceptance of differences); competence related to human activity, management (development and solutions of cognitive tasks, making atypical decisions, learning, planning, digital literacy) [2]. Thus, I. Zimnyaya describes competence as a content of the given abilities in the form of knowledge, skills and attitudes, whereas competency is viewed as an intellectual and personal ability of an individual to perform in a real and practical context [2]. Consequently, competency mirrors actual competence.

Owing to the recent reforms in education in Kazakhstan, it should be pointed out that students of senior stage of secondary school are aimed to be able to demonstrate what they have learned in school into real-life situations, the competencies they will need to perform are interconnected to their in-school and out-school contexts. Therefore, the lesson objectives and curriculum aims should always be focused on future profession as well as social integrated skills.

Consequently, in compliance with the purpose of our research, the historical overview of the concept of competency-based approach in profile education and education overall is provided.

As stated before, Kazakhstani educational policymakers have established the goal to align the standards of the educational system in compliance with a new reform to train high school students to become competent and effective users of in-school knowledge and be able to transfer it into real-life situations. This common aim prompts the shift from knowledge-based education to competency-based one, from teaching and learning to acquiring and performing various skills in different real-life settings. The process of the historical development and the current context of competency-based education have been undergone through the essential stages.

Fundamentally, competency-based education emerged in the United States in the 1970s in response to the call of required shifts and changes in education; it entails mastering competencies in learners that engage acquired knowledge in school into the real-life settings. During those years, there was a substantial gap between the necessities of the labor market and results of educational institutions, which were criticized for the lack of professional readiness to apply acquired knowledge and skills. J. Raven 
advances a revolutionary theory of competence and, throughout this process, identifies 37 competences important in today's society. These competencies include key components that some are relatively independent of each other, some relate to the cognitive area and others to emotional. These components are described as competencies of effective behavior [3]. Thus, it should be noted that this theory's fundamental notion is regarded within the psychological, social, and sociolinguistic contexts since competency-based education is not a set of fixed knowledge but a combination of personal and professional traits. The recent competency-based stage has been underway since the 1990s and can be characterized as a global development of active implementation in all educational institutions. The reason for increased attention was triggered and acknowledged by the Bologna Process. Within the joining to the Bologna Process, the role of competency-based approach was reconsidered in many countries including Kazakhstan and introduced into the profile stage of secondary school [4].

In contemporary education, competency-based approach refers to an educational movement or new philosophy in education, which focuses on practical-oriented ultimate outcome. This relates not only to acquiring the knowledge, but also to constructing the qualities essential for professional life and self-development. That is an initial stage for a life-learning education, which occurs throughout our life. In today's rapidly changing the world, there is a high demand for easily integrated competent people. Competency-based approach involves developing learners searching, analyzing, filtering, proceeding and conveying information skills as well as reflective and self-assessment skills. In this respect, the competence-based approach is a method for maintaining the educational balance with the needs of society, stakeholders, and labor market. Secondary education is one of the key contributions, which provides qualified and skilled human resources development [5].

Obviously, competency-based education is different from traditional approaches as it requires new technologies to provide all possibilities to entail the potential for learners to expand their in-school learning beyond the school settings.

Project-based learning is one of the crucial developments over the last two decades. There has been an educational revolution in the learning technologies. The historical roots of project-based learning date back to the late 1890s in experiential education, which was initially conceived by an American psychologist and educational reformer, John Dewey, who is believed as the father of the project approach, which was then developed further by his student Kilpatrick [6].

J. Dewey who was particularly critical of school education based on transmitting knowledge to the students emphasizes the connection between school and real life, theory and practice mainly focusing on the idea of learning by doing. He focuses on child-centered and real-life situations in a school environment [7, p. 20]. Consequently, the content and the topics for projects are selected by students and are often interdisciplinary; as a result, it activates the learning process, where students take some responsibility for designing their studies, which prepares them for real life that will be ongoing throughout adulthood.

Project-based learning has its deep roots in the constructivist approach and is reflected in J. Piaget [8] and L. Vygotsky [9] viewpoints. J. Piaget and L. Vygotsky were stating that learning occurs through real social interaction and an environment that supports individuals to develop cognitive challenges. L. Vygotsky, who introduced the 
theory of sociocultural approach and child's cognitive development, strongly believes that community plays a significant role in the process of making meaning [10].

Among many scholars who support the theory of project-based learning, it is worth emphasizing another prominent educator, a critical educational theorist P. Freire [11]. $\mathrm{He}$ is a high critique of the education system he labels as the banking concept of education, where students are seen as empty vessels to be filled with knowledge by teachers. P. Freire points out that in the banking concept of education, knowledge is a gift bestowed by those who consider themselves knowledgeable upon those whom they consider knowing nothing [11, p. 72]. In other words, the student is supposed to record and directly memorize information without understanding the real significance and questioning as oppressive.

The analysis of the studies has been shown that cognitive and behavioral theories of learning indicate that knowledge, thinking, experience and the environment for learning are inextricably tied. Learning, which is a part of the active social life occurs in a person's social community and culture by actively realizing their environment, where information is not merely transmitted from teacher to learner, but gradually and consciously constructed in the mind of the learner. Interaction with relevant issues and peers prompt learners to have the desire to explore, produce new solutions and share their experience, thus improving the process of learning and showing to educators, which approach, is needed to be used to amplify the abilities and skills of students effectively. Thereby, fundamentally project-based learning is a student-centered method based on a dynamic and constructivist approach that engages learners with real or realistic content where they construct their learning process, and plausible solutions addressed to the content and the effective applicability for professional guidance.

Consequently, the primary purpose of project-based learning is to create an environment where learners working in groups or teams are engaged with the learning process, in which they are supported to develop problem-solving skills, critical thinking, tackling the challenges, and identifying their own needs of inquiry to design an ultimate outcome. Throughout the whole learning process, learners explore what they know, what they need to learn, what they require to apply, realize, share, and finally perform for others. The emphasis is placed upon the whole process from the trigger to the final product, in which learners are facilitated to work collaboratively in groups to pursue the achievement. As mentioned previously, compared to traditional approaches, where the teacher is believed as the only source of knowledge, project-based learning is a way of learning where both students and teachers discover more and new things about themselves and the world around them. This brings motivation and satisfaction to the learning process and creates an environment where learners explore, interact, and connect the real world with their own in the target language. The interdisciplinary nature of project works paves the way for students to actively use language in the actual community and develop an awareness of the cultural dimensions.

The concept of a project and assigning it to students is not a new one. There is a deep-rooted tradition of doing projects in schools. However, doing a project is not the same thing as practicing project-based management (PBM). The analysis shows that traditional projects are considered as a range of short-term tasks that are often teacher-led, not relevant to students' lives, and do not resemble the work done in the real world $[12 ; 13]$. 
Under traditional projects, both students and teachers are focused on the product only and students are partially involved in the inquiry process. The teacher conducts the lectures, including planning, researching, and presenting all information to the students. Then, students complete the activities that are improved by the teacher, who is considered as a source of knowledge, and finally, students present their projects to the class, mainly to the teacher. While in PBM, students are engaged with the inquiry process from the very starting point, which drives the learning by thought-provoking questions.

\section{Methodology and research}

Larmer [14] indicates three levels of manifestation and practice of PBM: beginning, developing and high-quality or gold-standard. The high-quality PBM is meant to be an aspirational and desired level, which describes concrete indicators on how it looks like and what it means when it is appropriately applied. It is based on the timeline consisted of the stages and benchmarks, which gives educators and students a structure to build upon and to recheck along the process of inquiry and product development. It includes the following structurally advanced stages.

To understand if Project Management tools can be used in school projects towards competence-based learning, firstly we decided to define instruments to apply. Secondly, while providing an observation, following principles had been implemented into students' research projects. Finally, an interview was provided to analyze to what extent such an approach can be easily adopted and transmitted to teachers, who were expected to guide students under framed set of goals and instructions, instead of 'transmitting prepared information'.

Unstructured observation method was tapped into to observe the behavior. Structured interview was conducted to analyze if participants feel comfortable under such changes.

Since such manipulations are strictly prohibited within governmental schools, such a research could only be possible in private schools. This can be evaluated as a limitation of this research. To shrink the effect of the bias, we chose 86 senior students and teachers who guided them from two private schools in Almaty from a different locations and price categories and where we got an access as well.

The following Project Management tools had been applied.

Stage 1. Launching the Project Charter. The project is launched with the driving questions that engage and hook students into deep learning. A good driving question should eliminate the all-too-common student question by making the learning more purposeful [15]. J. McKenzie defines questions as the most powerful tool that leads to insight and understanding of a confusing world [16]. The questions or the problems can be created with students. Since the projects are focused on the real-world issues, student participation in selecting the question to discuss and the product to design is particularly important [17]. Collectively project's major product and individual learning objectives are defined, students develop a sense of responsibility, purpose and a group dynamic.

Stage 2. Roles of project designers and initial research. Having the goal and the learning objectives in mind, the teacher assigns the students their roles and, together 
with students, determine initial information needs and ways so that they feel more responsible and motivated for their work.

Stage 3. Benchmark check or Work Breakdown Structure (WBS). Benchmarks are known as the strategy of mapping the project backward and dividing it up into steps and manageable pieces and checkpoints for feedback [18]. Benchmark might have checklist of learning objectives; however, they do not refer to the final assessment of the product. A benchmark also includes reflection and a completion point to fulfill the gaps before they move to the next stages.

Stage 4. Developing the data, revising the product. This stage is the core of the project. Students may often go back and forth between this stage and the previous one to discuss feedback and recommendations to include. Students learn how to collect information by conducting experiments, online questionnaires or interviews; they filter and collect information by interviewing the informants or even invite or visit the content experts to benefit their experience on the issue. Another important activity in this stage is to brainstorm the ideas for the final product, which can be a website, brochure, video, article, performance, an exhibition for parents.

Stage 5. Benchmark check. Students present their draft versions of their research or product with initial information demonstrating the appropriateness of their idea. Again, students get feedback from the teacher and their peers, share any relevant information related to the final product. They follow the checkpoints that every student or group member needs to accomplish. Benchmarks are one of the key mechanisms for providing structure in PBM and are needed as many as students need scaffolding. They track students and keep teachers in touch with their learners.

Stage 6. Bringing it all together. Preparing a product to present is the big finish and busy time for the project. Students polish up their products and make it be performed in public. However, this stage can be make-or-break time, students' work might seem well prepared until teacher realizes the project does not comply with the high-quality product or does not meet the learning expectations and objectives, thereby by managing this stage well will avoid disaster [19, p. 125].

Stage 7. Presentations and exhibitions. The variety of ways to present the work depends on the nature of the project. The project presentation can be tied and aligned to another public or school event. A public event or exhibition is a great way to help the community, parents and school administration to understand and build the PBM culture. The effect of the information mixture gives a dynamic view of the message, due to which we unpack the contents of this message and as if we ourselves come to certain conclusions about this situation [20].

Stage 8. Evaluation, reflection, and celebration. After the big finish, it is important to involve students in the reflection and consolidation process. Students discuss the challenges and difficulties, evaluate their performances, and make a final assessment of how well they completed the task and collaborated with each other. Students identify what they have learned and what they need to improve. The wrap-up stage of the project process is a celebration of the students' achievements.

\section{Results and discussion}

The open-ended responses allowed identifying the degree of awareness and concern for the organization of project activities at the senior stage of the secondary 
school on the basement of project-based management. According to this open-ended section, the majority of the teachers demonstrated the awareness of what PBM was, its importance in teaching and learning and how it can be developed in the context. Picture 1 represents data in which the participants were asked whether they have encountered any challenges and to what extent they have faced the challenges to promote PBM productively. According to the gathered data, participants clearly expressed that they experienced challenges and obstacles: either "up to a certain extent" (65\%) or "very much" (14\%). Nonetheless, $19 \%$ of participants stated, "No, not particularly," and very few, $2 \%$ indicated that they had not experienced any challenges regarding the issue.

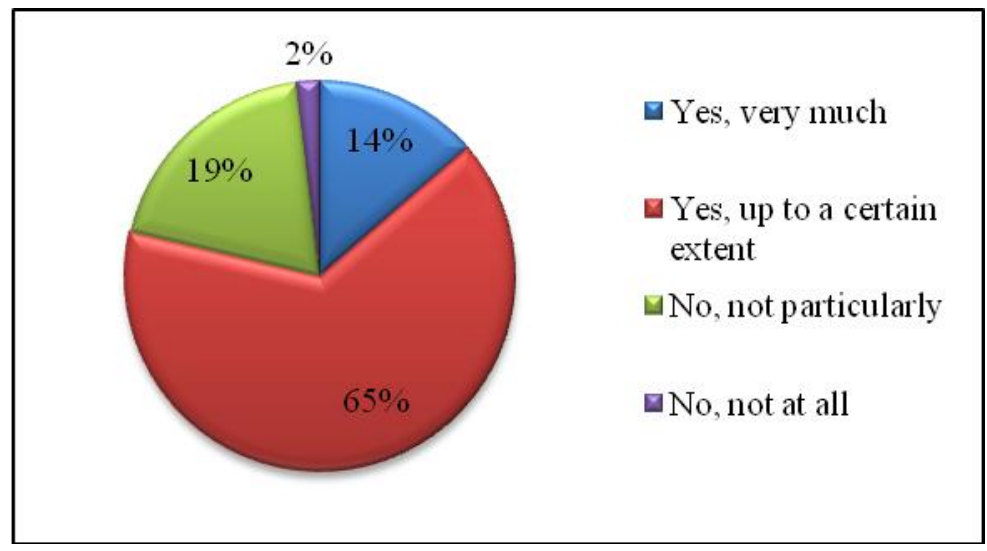

Fig. 1. Percentage of respondents facing the challenges in PBM

Since most participants experienced challenges either "up to a certain extent" or "very much" the data indicates that the respondent group does not hold a stable position on using PBM for profession-oriented work at the senior stage of the secondary school. It involves a change from traditional methods of instruction.

Furthermore, participants were asked if they got any support from school administration while implementing PBM to organize guidance for students. Data from the questionnaire show that the majority of participants acknowledged the support they got from school administration (Picture 2): either "up to some extent" (41\%) or "yes, always" (14\%). However, a considerable percentage of responses $31 \%$ "No, not particularly" and $14 \%$ "No, not at all" stated that they did not receive any support from school administration.

Participants supplemented their answers with the examples of support that they ask from their schools. The respondents noted various requests including financial support, transport, technical equipment, permissions to organize projects and permissions for trips out of schools, and seminars or training considering PBM.

Finally, it is worthwhile to highlight what causes to weak project. The studies present certain characteristics of the so-called project that make it poor or not PBM at all. 
Gold standard PBM begins with a good driving question, which reminds students why they are undertaking the project. Therefore, if PBM is intended to be structured around a simple question, it will not set the tone of inquiry, which may lead to a non-PBM environment. A project without a good driving question is like an essay without a thesis. PBM is a particularly expedient path to the goal, an efficient and rigorous way to prepare students for what lies ahead. When a project is not used as a tool or a method of instruction aligned to standards but a goal, students will not be able to grapple complexity and engage in active learning.

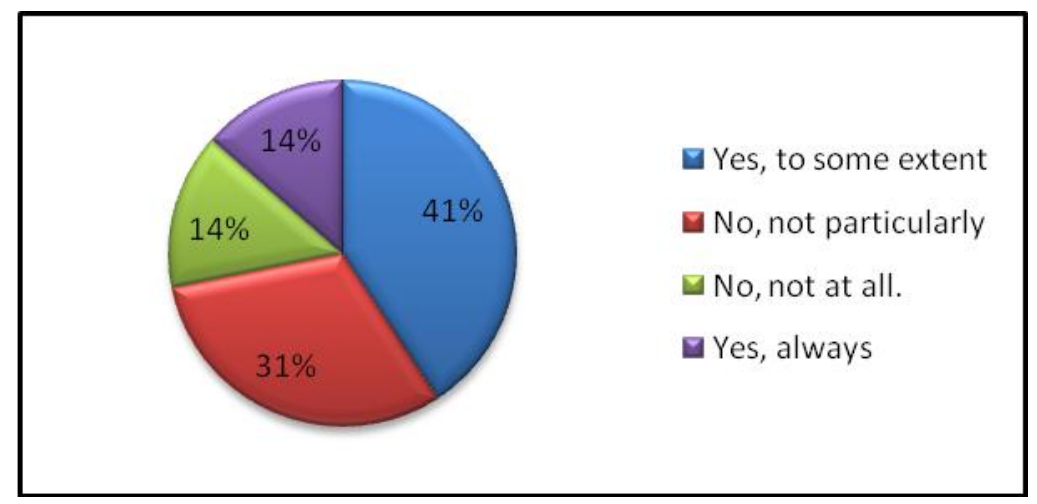

Fig. 2. Percentage of ratings for support participants receive in implementing PBM

The empirical studies demonstrate the increased academic achievement, the development of the significant skills, namely problem-solving, critical thinking, interpersonal and communicative skills, as well as the students' active engagement in the learning process when project-based management is applied. This analysis witnesses the demand for changes from traditional instructions to deep reflective learning through investigation, inquiry and exploration.

Thus, contemporary education and the demands in today's society acknowledge the necessity of a learner-centered and participatory educational approach, which can lead to the shift from content-based to competency-based and from traditional to contemporary approaches. Project-based management comparatively to traditional learning and traditional projects engages students with the inquiry process from the very starting point, which drives the learning by thought-provoking questions throughout the learning process. Thus, with student learning goals in mind gold standard PBM embodies following essential features.

Challenging problem or question- relates to a good driving question based on the real-life challenge. While doing a project, learners need to brainstorm certain openended intriguing questions, which will direct them to identify what should be included and excluded that will help them to frame their exploration [21].

Sustained inquiry is a consequence of challenging problems or questions used to launch an ongoing process of asking questions, problem solving, and applying new knowledge by interviewing experts, doing fieldwork, or conducting an experiment. As 
students answer their initial questions, the new question arises, thereby becoming a chain or a spiral of deep learning. Moreover, it is believed that well-designed and carefully planned projects develop student inquiry that will guide to professional goals.

Authenticity refers to making learning experience through real-world issues. PBM explores four different ways for authentic projects, possibly held concurrently. First, the context of the project matches what happens in the actual world. The tasks students complete in the project match what people do in the real world. It can have an authentic impact on real world by proposing doable work or changes and finally, a project can carry personal authenticity, which reflects and engages students' personal concerns, issues from their lives, values, language and cultural aspects of student's community. The projects containing the aforementioned multiple forms of authenticity are more powerful and productive than projects with less authenticity.

Student voice is a key feature, which makes the project more meaningful. Due to this feature, project-based management as a learner-centered approach emphasizes the student's significant voice in choosing the content area and project topic [22]. Thus, PBM focuses on students' understanding of what they are doing, its importance, and the way of its evaluation. As a result, this learner-centered element contributes to learner's level of intrinsic motivation and active involvement, which are essential for the meaningful project-based management process. It is important to note that the amount of voice and choice teacher gives his/her students depends on students' readiness to handle and teacher' abilities to scaffold and coach. Therefore, the more choice is given, the better it is for students to make logical choices in the future.

Reflection is another key part of an active project. When reflection is implemented in one's own thinking, it refers to metacognition [23]. Thereby, reflection is divided into two sides: cast outward, which prompts students to improve thoughtfully throughout the whole learning process and behave appropriately and cast inward, develops an awareness of learning and problem-solving strategies that encourage students to alter these strategies appropriately.

Critique and revision are also emphasized as important components that should be involved throughout the development process of the product or solution to the driving question. The feedback received from the teacher and their peers or other experts should motivate students to revise and improve their product and pursue their in-depth inquiry. Building the process for critique and revision throughout the project prompts meaningful learning as it includes many efforts for it. Students learn that not everything can be perfect within a first trial; thereby, revision is one of the features that make the project real and meaningful. Observation of intergenerational discourse of everyday interaction among youngsters at home (with parents, elder siblings), at educational institutions (with teachers, administration) and in different places (cashiers, shop assistants) showed that youngsters tend to keep social identity verbally among peers and shift to other language registers and another linguistic behavior with adults [24].

Public product is a final component in which students need to present their solutions or answers to the driving questions to numerous audiences beyond the classroom or even school, which may include parents, content experts or the global community presented via live presentations, printed documents or social networks. Presenting 
their work publicly helps students motivate them to create high-quality products. It is believed that when students are presenting to the real audience they tend to care more about its quality. The sense of evaluation and interest make them become more aware of their product and learning process in which students develop $21^{\text {st }}$ century competencies [25].

\section{Conclusion}

The article presented the methodology of the PBM implementation for the organization of profession-oriented activities for the students of the senior stage of the secondary school. Having analyzed the theory of PBM, we consequently determined the key components of PBM and teaching practices. The comprehensive model of the PBM was elaborated to provide profession-oriented project activities for senior students of high school. The article revealed the results of the study conducted to investigate the current situation regarding the PBM implementation in actual teaching in the Kazakhstani schools. From the analysis of the preliminary studies with 103 teachers from secondary schools, the following can be concluded. The most commonly shared objectives of Kazakhstani teachers are to improve proficiency to encourage students to choose the profession, to continue their education and behave appropriately with people from different cultural backgrounds. The results of the analysis of responses on teachers' awareness and beliefs reveal that they are familiar with the concept of PBM. Demonstrating the awareness and the importance of PBM, teachers expressed the awareness of PBM dimensions. Despite the fact that the teachers understand the concept and the significance of PBM in education, the results indicate that teaching and practicing PBM in their classes are still challenging, regardless of any teaching experience. The findings of this study reveal several crucial difficulties that create obstacles to promoting PBM. First, teachers recognize the lack of a real environment for students to understand their interests and inclinations. Other important problematic aspects include the teachers' lack of knowledge on what to do in order to promote PBM, how to teach within the frame of PBM, how to assess it. All these challenges are seen as more problematic for teachers, as they indicate a great need for further research, training and recommendations with the focus on the implementation of PBM. Thus, teachers seem to be focused on integrating the aspect that they find most challenging. There appears to be no apparent and definite relationship between teachers' awareness of the concept and its integration into their teaching practice. Although teachers report having a positive attitude to PBM. The reasons may be the above- mentioned challenges teachers face: lack of an environment for learners to interact with people of their future profession, lack of knowledge of teachers on how to integrate profession-related aspects. Finally, the article presented the results regarding the PBL implementation in schools. The most frequently indicated type of PBL that the teachers participated in a class type PBM, which may show the teachers' awareness; however, in addition, it suggests the single-class oriented projects and a lack of collaboration with other students and teachers of different subjects. Even though the teachers acknowledge the support provided by school administrations, they reported various challenges regarding the PBM implementation in their schools. For instance, the lack of time to plan and practice PBM emerged as an essential obstacle, as well as the weak involvement of other interdisciplinary teachers to establish the collaboration within the 
schools and other experts of specific areas. Furthermore, the study reveals that teachers are aware of the essentials needed for gold-standard PBM as they wanted their school administrations to help them with the real audience and public events, which suggests the importance of engaging students with an authentic professional environment throughout the learning process. It is interesting to note that the responses in this study were of encouraging and complaining nature showing concern over the obstacles in implementing PBM, which leads to the teachers' awareness of what Project Management is, how it works, and its importance and belief of PBM as a practical teaching approach in classrooms.

\section{References}

1. Conception of Development of Profile Training in the Republic of Kazakhstan, 2009, p. 1-15.

2. Zimnyaya I. A. Key competencies - new paradigm of the results of education. Contemporary higher education, 2003, p. 34-42.

3. Raven J. Competence in modern society: Its identification, development and release. HK Lewis, 1984, 2002.

4. Process B. Bologna Declaration. The European Higher Education Area, 1999, Jun.

5. Smakova K., Islam A. Competency-based approach in foreign language education. Abai Kazakh National Pedagogical University Bulletin of Pedagogical sciences, 2019, vol. 2 (62), p. 98-104.

6. Simpson D. J., Stack S. F. Teachers, leaders, and schools: Essays by John Dewey. SIU Press; 2010, Oct 27.

7. Dewey J. The relation of theory to practice in education, 1904.

8. Piaget J. To understand is to invent the future of education. New York, Grossman, 1973.

9. Vygotsky L. S. Mind in society: The development of higher psychological processes. Harvard University Press, 1978, 1980, Oct. 15.

10. Vygotsky L. S. The collected works. Problems of general psychology. R. W. Rieber and A. S. Carton (eds.). New York, NY, Plenum, 1987, vol. 1.

11. Freire P. Pedagogy of the oppressed. New York, Continuum. Revised 2005, 2018. URL: https://commons.princeton.edu/inclusivepedagogy/wp-content/ uploads/sites/17/2016/07/freire_pedagogy_of_the_oppresed_ch2-3.pdf

12. Mayer A. What is the Difference Between Doing Projects and Project Based Learning. Fried technology: education technology \& professional development, 2018. URL: https://www.friedtechnology.com/post/projects-vs-project-basedlearning

13. Curtis D. Project-Based Learning: Real World Issues Motivate Students, 2001. URL: https://www.edutopia.org/project-based-learning-student-motivation

14. Larmer J., Mergendoller J., Boss S. Setting the standard for project based management. ASCD; 2015 May 26.

15. Boss S., Larmer J. Project based teaching: How to create rigorous and engaging learning experiences. ASCD; 2018 Sep 20.

16. McKenzie J. Scaffolding for success. The Educational Technology Journal, 1999. vol. 9 (4). 
17. Solomon G. Project-based management: A primer. Technology and learningdayton, 2003, Jan 15; 23 (6), p. 20.

18. Lenz B., Wells J., Kingston S. Transforming schools using project-based management, performance assessment, and common core standards. John Wiley \& Sons, 2015.

19. Larmer J., Mergendoller J., Boss S. Setting the standard for project based learning. ASCD; 2015 May 26.

20. Nurbayeva A. Cognitive Mechanisms of Kazakhstan Commercial and Social Advertising Text Opción. Año 35, no. 88 (2019): 280-303. ISSN 1012-1587 / ISSNe 2477-9385

21. Bell S. Project-based learning for the $21^{\text {st }}$ century: Skills for the future. The clearing house, 2010, Jan. 29, vol. 83 (2), p. 39-43.

22. Hattie J. Visible learning for teachers: Maximizing impact on learning. Routledge, 2012, Mar 15.

23. Hmelo-Silver C. E., Duncan R. G., Chinn C. A. Scaffolding and achievement in problem-based and inquiry learning: a response to Kirschner and Sweller. $E d$ ucational psychologist, 2007, Apr. 26, vol. 42 (2), p. 99-107.

24. Bekzhanova $\mathbf{Z h}$. Constructing typology of youth discourse based on the analysis of authentic language sources. Journal of Language and Literature, 2015, vol. 6, no. 2, iss. 2, May. ISSN 2078-0303.

25. Golovchun A. A. The development of Research Competence Through Digital Technologies. Talent Development \& Excellence, 2020, vol. 12, no. 1.

Материал поступил в редколлегию 12.11.2020

Принят к печати 12.01.2020

The article was submitted 12.11.2020

Accepted for publication 12.01.2020

\section{Information about the Authors}

Erkezhan T. Meirkhanova, Post-Graduate Student, Kazakh National University after Al-Farabi (Almaty, Kazakhstan)

Yerkezhan.meirkhanova@gmail.com

Saule T. Kupeshova, Senior Teacher, Kazakh National University after Al-Farabi (Almaty, Kazakhstan)

s.kupeshova@gmail.com

Scopus Author ID 57203642899 


\section{Сведения об авторах}

Мейрханова Еркежан Талгаткызы, аспирант, Казахский национальный университет им. Аль-Фараби (Алматы, Казахстан)

Yerkezhan.meirkhanova@gmail.com

Купешова Сауле Телеухановна, старший преподаватель, Казахский национальный университет им. Аль-Фараби (Алматы, Казахстан)

s.kupeshova@gmail.com

Scopus Author ID 57203642899 